\title{
11 Persistent paradoxes, turbulent times
}

\author{
Gender equality policies in the \\ Nordics in the 2010s
}

\author{
Johanna Kantola
}

The Nordic countries are internationally known for their high levels of gender equality. 'Gender equality' has indeed become both a central component of the countries' national identities and even an export item, especially for Sweden, which has been seen to offer its good practices and policies to other countries. The Nordic model of welfare states is intrinsically connected to the issue of gender equality and the Nordic states have both promoted gender equality and benefited from it. The extensive public sector has offered jobs for women and care for their children, thus enabling women's participation in the labour market. The ideas about what gender equality consists of - the so-called Nordic discourse on gender equality - are firmly intertwined with the policies and institutional practices of the welfare states. ${ }^{1}$ Ideologically, the discourse has promoted equality of outcome as opposed to more liberal notions of equality of opportunity. This sets the Nordic ideas about gender equality apart from many other European countries and the European Union (EU).

At the same time, gender scholars within Nordic countries have long worked to expose the remaining gender inequalities and the paradoxes of the Nordic model: high levels of violence against women, gender-segregated labour markets, gender pay gaps, and masculine domination in politics. Paradoxically, despite high levels of gender equality, Finland, Sweden and Denmark top European domestic violence rates. ${ }^{2}$ Gender pay gaps are at a comparatively high level too, around 16 per cent in Finland in 2019, compared to 10.7 per cent in Sweden in 2018. ${ }^{3}$ In politics, gendered practices devalue women's expertise in, for instance, economics and foreign policy. Women find it difficult to combine motherhood and a political career. Moreover, hate speech has made the positions of young women politicians particularly vulnerable. ${ }^{4}$ Outright misogyny has been revealed, although not thoroughly discussed, in Finnish and Swedish politics by the \#MeToo campaign against sexual harassment. ${ }^{5}$ Gender scholars have worked together with the women's movement and femocrats within the state to develop gender policies and policy making tools to tackle gender inequalities.

Feminist scholars have turned their attention to the Nordic countries to analyse the effects of neoliberalism on gender equality and policies. ${ }^{6}$ In the Nordic countries, neoliberalism has questioned some of the basic tenets of gender 
equality policy including: the central role played by the welfare state in providing jobs and universal services; state institutions advancing gender equality and not outsourcing these jobs to projects and third sector actors; and the very definition of equality as a political value. ${ }^{7}$ Each of these has been evaluated in terms of efficiency: markets, third sector and competition are easily deemed more efficient than state-based services and structures. With this trend, paralleling the debates on the crises of the welfare states, notions of 'equality' more generally, and 'gender equality' more specifically, have been challenged. With the rise of neoliberalism and New Public Management (NPM), 'equality of outcome', which the Nordic framework has been based on, appears old-fashioned, a drag on an otherwise dynamic economic system, and demanding too much focus on structures of inequality and placing too little emphasis on individual merit. ${ }^{8}$

The changes in the equalities framework have been accompanied by the widening of categories of inequality from gender and class to cover multiple inequalities including, most commonly, race and ethnicity, religion and belief, sexual orientation, age and disability. For gender equality, this signifies that gender as a category can no longer be considered in isolation from other bases of inequality. Feminist theory employs the concept of intersectionality ${ }^{9}$ to highlight the ways different inequalities intersect, leading to unique forms of discrimination, for example, for ethnic minority women. The challenges posed to the Nordic discourse of gender equality by multiculturalism have been discussed in scholarly debates drawing attention to the extent to which it has mainly benefited majority women and men. ${ }^{10}$

The objective of this chapter is to explore a central paradox: how the model countries for gender equality fail to increase levels of gender equality. A persistent challenge has been that gender equality has been characterized by good policies on paper, which suffer from an implementation gap in practice. ${ }^{11}$ In the 2010s, in Sweden, the impact of neoliberal discourse and policies, and, in Finland, the impact of the economic crisis and austerity politics, have been argued to be detrimental to gender equality policies. ${ }^{12}$ This chapter explores how - when combined with the influence of populism, nationalism, and conservatism - the limitations and vulnerabilities of the Nordic model become visible.

\section{The Nordic model for gender equality: does it exist or did it ever?}

\section{The Nordic model of women-friendly welfare states}

Gender equality has been argued to be 'one of the most prominent hallmarks' of the Nordic welfare model and its distinctive welfare state character. ${ }^{13}$ In feminist debates, the countries have been described as 'women-friendly welfare states', a term coined by Helga Maria Hernes (1987). The term sets Nordic feminist perspectives on the state apart from the more Anglo-American feminist theories about the state. A central dynamic of friendliness towards women was, according to Hernes, the interplay between a broad political mobilization 


\section{Johanna Kantola}

of women 'from below' and responses 'from above' in terms of state feminism and institutionalization of gender equality. This interplay differed considerably, however, Sweden was the most institutionalized and Denmark was the most bottom-up-oriented gender model, whereas Norway and Finland have taken a middle position. ${ }^{14}$ Another central feature was the fact that the male breadwinner model was abandoned, and Nordic women gained economic autonomy relatively early compared to women in other Western countries. It happened first in Finland in the 1950s, in Denmark and Sweden in the 1970s and in Norway in the 1980s. ${ }^{15}$ Hence, the benchmark for women's employment at 60 per cent in 2010 in EU's Lisbon Strategy was already reached in the late 1970s and 1980s in the Nordic countries. Furthermore, Nordic women gained a voice, and the political representation of women was for many years ranked among the top five in the world.

In more recent research, the concept of the women-friendly welfare state has been theorized as a powerful discourse that silences issues such as domestic violence or sexuality and promotes certain subject positions for women and men. ${ }^{16}$ As a discourse, the women-friendly welfare state has fostered a belief in decision-makers and citizens alike that the state is 'good': for instance, in case of serious societal problems such as domestic violence, it is believed to provide services to victims. However, this has not been the case in Finland where there has traditionally been a serious lack of services provided, and the country has been called a laggard and underperformer with respect to services and legal change in relation to violence against women. ${ }^{17}$ The discourse on the women-friendly welfare state makes it harder to fight the problem as there is a belief that things are fine in the model country of gender equality' where gender equality has already been achieved. The concept of the women-friendly welfare state has also been studied as a particular normative notion based on Nordic values of equality that have been exported to the EU and its member states as well as to other parts of the world. ${ }^{18}$

The Nordic experience has exposed some paradoxes connected to the dominant vision of gender equality. In this vision, the key aim has been to achieve equality through integration of women in the labour force. The Nordic labour markets are highly gender-segregated into public female-dominated and private male-dominated sectors. A gender gap in wages and incomes that is closely related to this segregation and the division of care in the family has persisted. Despite many women having a high level of education, which has exceeded men's, the share of female managers is restricted. Another example comes from the jobs provided by the women-friendly welfare state to women. Paula Koskinen Sandberg argues that jobs in the government sector have deeply institutionalized lower pay and position for women. ${ }^{19}$ The struggles around, for example, increasing nurses wages in Finland illustrate the difficulties of achieving higher pay levels for women in low-paid public sector jobs and in a corporatist system where wages are negotiated between male-dominated labour market organizations. ${ }^{20}$ 
Nordic models differ in many ways from other European and EU ways of promoting gender equality. The EU traditionally used anti-discrimination law to advance gender equality, for example, in relation to equal pay, social security and labour markets. ${ }^{21}$ Unlike in the EU, in the Nordic countries, the tradition of promoting gender equality is in many ways connected to welfare state policies and corporatist procedures discussed previously. ${ }^{22}$ Equality is understood as a social concept connected to social justice rather than to the liberal individualist framework. This means that a number of issues that have been elsewhere seen as inequalities that need to be outlawed with anti-discrimination measures (such as equal pay in the EU) have been treated with welfare policies or positive measures and discussed as labour market issues in corporatist working groups in Nordic countries. These ideas about gender equality and its promotion have been firmly intertwined with each country's institutions and policies. Gender equality there has been established as a labour market and social welfare issue rather than as an inalienable right to non-discrimination. ${ }^{23}$

In such a setting, anti-discrimination law was not seen as a primary tool for enhancing equality. As a result, gender equality policy has traditionally relied on positive measures. ${ }^{24}$ Anti-discrimination law aims at creating a level playing field and equal opportunities by outlawing discriminatory practices. In cases of discrimination, however, it places the responsibility on the individual that has been discriminated against to pursue the case, for example, by taking it to court. Positive measures, by contrast, aim at correcting initial disadvantages and embody a different notion of gender equality. Instead of aiming at equal opportunities, positive measures aim at substantive equality and equality of outcome. Such notions of equality are based on the idea that it is appropriate to deviate from formal equality (equal opportunity) in order to make the position of the underrepresented group better. ${ }^{25}$

Concrete positive measures used in the Nordic countries include quotas, for example, for company boards, especially in Norway. ${ }^{26}$ In addition, states have relied on gender mainstreaming and different responsibilities placed on employers and public authorities to promote gender equality in workplaces, in pay, or in education. ${ }^{27}$ Positive measures then operate on the basis of a fundamentally different logic. They remove the responsibility from the individual and make it the employers' duty to change certain structures (e.g. working hours) that may put the underrepresented group at disadvantage (e.g. late meetings being difficult to attend due to childcare responsibilities). At the same time, gender action plans have been vulnerable to attempts to make states and governments more efficient. For example, gender action plans under conservative governments in Finland have been reduced in style and form to a narrow range of bullet points, and the political character of gender equality questions has disappeared. ${ }^{28}$

Despite these similarities, Nordic countries have distinct gender profiles in relation to the institutionalization of gender policy, women's movement organization, and ideological emphases placed on motherhood or liberty. ${ }^{29}$ For instance, in Denmark, gender equality policies have been thinner than in other Nordic countries and liberalism has informed both the women's movement 
and state activities to a greater extent than in other Nordic countries. ${ }^{30}$ In Norway, the ideology of motherhood has been prominent. In Finland too, the state-funded Home Care Allowance has resulted in mothers staying at home to a greater extent than in other Nordic countries with children under the age of three. In Sweden, the impact of feminism and the willingness to analyse gendered power structures, for instance, when implementing gender mainstreaming, has been stronger than in other Nordic countries. ${ }^{31}$

\section{Shortcomings and blindspots}

Notwithstanding the differences, the Nordic gender equality discourse has been argued to suffer from similar shortcomings. The consequences of the ideational constructions of gender equality and its institutionalizations have been extensively explored. It has been argued that the highly developed social policies for parents have in fact reproduced gender segregation and inequality in the family and the labour market, among other things, because more women than men tend to take parental and childcare leaves. ${ }^{32}$ The emphasis placed on social rights and welfare policy has resulted in women's bodily rights, for example, in relation to violence against women, receiving less attention. ${ }^{33}$

While the idea of friendliness towards women of Nordic welfare states has been based on the premise of an idea of women's common and collective interests, ${ }^{34}$ it has become evident that Nordic gender policies have been only directed at some women (and men) and may, in fact, increase inequalities between women. Postcolonial feminists have challenged the grand vision of women-friendly welfare states, arguing that this vision has been based on the situation of white, middle-class women. ${ }^{35}$ Gender equality is at the centre of the debates on immigration and multiculturalism in these countries and helps to define who belongs to the welfare states. ${ }^{36}$ In this process, the Nordic discourse on gender equality is constructed in opposition to these 'others' ${ }^{37}$ For example, in Denmark, there has been a turn towards discussing gender inequality as a cultural problem prominent among immigrant minorities as opposed to majority Danes among whom it has already been achieved. ${ }^{38}$

In this way, 'the passion of equality' has been questioned, also because the Nordic countries in international comparisons fare relatively worse in reducing inequalities between ethnic majorities and minorities, compared to their achievements in relation to class and gender. ${ }^{39}$ Postcolonial critiques of Nordic welfare states and Nordic feminist practices and scholarship problematize the ways in which discourses on nationhood, belonging and welfare states construct categories such as immigrants. ${ }^{40}$ They can, for example, be constructed as in need of special education about gender equality or as the likely perpetrators of violence.

In relation to outlawing discrimination on bases other than gender - race, ethnicity, disability, age, sexual orientation - the impact of the European Union's anti-discrimination law becomes significant. Since the Lisbon Treaty and new directives in the 2000s, EU anti-discrimination directives have outlawed 
discrimination on the basis of not only gender but also race, ethnicity, religion and belief, age and sexual orientation. ${ }^{41}$ For example, in Finland, the need to transpose EU directives resulted in the country's first non-discrimination law which outlawed discrimination on the basis of these other categories of inequality and not just gender. ${ }^{42}$

Both European soft and hard laws have shaped national policies and discourses in the Nordic countries, and have been used in different ways by domestic actors. Overall, the EU directives have moved the countries towards stronger provisions against discrimination. ${ }^{43}$ The EU frameworks have also changed the gender equality discourse in these countries. Some of the subtle trends that have been identified in scholarly debates in the gender equality discourse include becoming more technical, managerial and individual based, ${ }^{44}$ focusing more on protecting motherhood ${ }^{45}$ and moving away from the universality of welfare services because of EU-funded local workplace-specific gender equality projects. ${ }^{46}$ These shifts are subtle and uneven, yet, may result in more fundamental changes in discourse and practices over time.

\section{Current challenges to gender equality in Finland: neoliberalism, conservatism, nationalism}

By way of example, the case of Finland illuminates some of the current challenges to the type of equality regime described previously. I recently studied the issue with Anna Elomäki exploring the impact of the right-conservativepopulist government in power since 2015 and how it has significantly intensified austerity politics, weakened gender equality policy and harshened immigration policy. The Finnish political context and the government's policies are underpinned by three political projects: neoliberalism, conservatism and nationalism. ${ }^{47}$ These gendered projects converge in public policies and discourses in a manner that poses particular challenges for gender equality and feminism. Much of the feminist literature on the relationships between these three projects has focused on the combined effect of neoliberalism and conservatism. ${ }^{48}$ Notably, various policies in Finland draw on not only neoliberalism and conservatism but also nationalism to ensure their success. In other words, Finland recently faced a political moment where the three political projects of neoliberalism, conservatism and nationalism came together to form a 'triangle' informing public politics. ${ }^{49}$ While the focus of this section is on Finland and the unique impact of the conservative-right-populist government 2015-2019 and its impact of gender equality policies, neoliberalism, conservatism and nationalism pose challenges to the other Nordic countries too, even if the effects and timings are likely to vary across the countries.

The figure of a triangle as an analytical tool illustrates the particular challenges that the convergence of neoliberalism, conservatism and nationalism poses to feminism. ${ }^{50}$ When looking at the traditions of women and feminist mobilization, it is evident that Finland has a strong feminist tradition in areas where the women's movement has cooperated closely with the state (manifested in 
patterns of state-based funding, practices of consultation and hearings on legislative and policy proposals, and close personal networks between actors).$^{51}$ Parts of the women's movement have furthermore become increasingly professional and specialized. Finland has an established set of women's organizations that work on their specific niche issues: mainstream gender equality policy, minority women, sexual equality, or human rights. Each organization has specialized in advancing certain forms of equality or challenging particular inequalities. In such a context, austerity politics and increased visibility of conservative values and anti-immigration stances created the new dynamics. ${ }^{52}$

Of the three political projects that became so visible, the detrimental impacts of neoliberalism - marketization of public services, transferring of costs and risk from the state to individuals and families; employment and social policies that give responsibility to individuals; and governance reforms that extend private sector management practices to the public sector - on the Finnish 'women-friendly' welfare state have been extensively explored. ${ }^{53}$ As elsewhere, recent economic and financial crises have provided opportunities to advance the neoliberal project. ${ }^{54}$ The conservative-right-populist government of Juha Sipilä adopted significant cuts in public services and benefits, including the dismantling of the hallmark of the women-friendly welfare state, namely the statutory right to public childcare for all children. It has also proposed to corporatize and marketize public social and healthcare provisions and transfer costs from employees to private employers in order to increase international competitiveness. ${ }^{55}$

The long-standing influence of conservatism, which we defined narrowly as a conservative stance on moral and ethical issues that involves the promotion of conventional family structures and gender roles, ${ }^{56}$ has meant that the Finnish welfare state has been weaker and less 'social-democratic' than its Nordic counterparts. The influence of conservatism is visible in, among other things, the Finnish care regime that provides financial incentives for parents to care for their children at home as well as in the long-standing political neglect of intimate partner violence. ${ }^{57}$ The visibility of traditional views on gender and family has in the past years increased in political and public speech, and they now shape government's gender equality policies through the Centre Party and The Finns. The 2015 government programme was the first in 20 years that did not mention gender equality as the goal of the government, and gender equality policy has been narrowed with regard to the long-standing goal of more equal division of care between women and men. ${ }^{58}$ The higher status given to family was manifested in that for the first time there was a designated government minister for family affairs, but no designated minister for gender equality in 2015-2019. While the anti-abortion views of two of the three leaders of the coalition parties did not lead to new restrictions in the area of reproductive rights, the conservative agenda gained visibility through a citizen's initiative to allow health care personnel to abstain from prescribing or performing abortions due to reasons of consciousness. ${ }^{59}$ Foreign Minister Timo Soini (The Finns/ 
The Blue Future) participated in an anti-abortion march in Canada causing a vote of confidence in the parliament but no resignation. ${ }^{60}$

The third political project informing gender equality policy today is nationalism, which can be defined as exclusionary politics of closed borders and racialized distinctions between 'us' and 'them' expressed in the growing support for far-right populist parties. ${ }^{61}$ Anti-immigration, anti-multicultural and racist arguments have become more visible and acceptable in public speech since the populist Finns Party became the third largest party in the parliamentary elections of 2011, entered the government in 2015, and illustrated its consolidated position despite an internal split by becoming the second-largest party after the 2019 parliamentary elections. ${ }^{62}$ While strict immigration policy has been characteristic of Finnish policy for decades, the policies were hardened since the Finns Party entered the government in 2015 and were able to set the political agenda and dominate the political discourse about immigration and multiculturalism in the face of the increasing numbers of refugees to Europe. The party worked to ensure Finland would not be an attractive country for refugees by reducing benefits, legislating stricter rules for family reunification ${ }^{63}$ and shaping Finland's EU relationship by refusing to agree to the common compulsory refugee allocation policy and quota mechanism. The anti-immigration policies and the racist rhetoric have been gendered: Finnish women were to be protected from the violence of another culture's men. ${ }^{64}$

As evident from the Finnish case, gender plays a central role in all three political projects and each of them poses challenges for gender equality and feminism. ${ }^{65}$ While neoliberal discourses and policies portray both women and men as rational economic actors and push women to the labour market, policies that dismantle the welfare state and re-privatize and informalize care rely on and intensify women's unpaid or poorly compensated work, increasing class-based and racialized inequalities among women. ${ }^{66}$ Conservatism, in turn, can be seen as an explicitly anti-feminist force that relies on and promotes traditional views on gender and the family and resists changes in these areas. ${ }^{67}$ Gender relations play a crucial role in all nationalist projects, ${ }^{68}$ and racializing nationalist projects appropriate notions of gender equality and gendered violence for their own purposes and are closely connected to anti-feminism, misogyny and views that 'gender equality has gone too far' ${ }^{69}$

Although neoliberalism, conservatism and nationalism are gendered in different ways and pose distinct challenges to gender equality and feminism, they may work against gender equality in mutually reinforcing ways. Feminist theorists have conceptualized the relationships between the three political projects mainly in pairs, focusing on the relationship between neoliberalism and conservatism. ${ }^{70}$ One of the most well-known accounts is Wendy Brown's analysis of the convergence of the 'economic-political rationality' of neoliberalism and 'moral-political rationality' of conservatism. ${ }^{71}$ In different national contexts, the coalition between neoliberalism and conservatism has been seen lead to doubly unfavourable conditions for the women's movement. ${ }^{72}$ It has also been 
suggested that due to the convergence of neoliberalism and conservatism, it has become difficult for feminists to reject one without embracing another. ${ }^{73}$ The relationship between conservatism and nationalism and its significance for feminism has been addressed mainly in research on right-wing populism, in which conservative views on gender and the family meet a harsh anti-immigration stance and racism. ${ }^{74}$ The links between neoliberalism and nationalism have been explored in research on the connection of 'welfare chauvinism' targeting migrants to the neoliberal restructuring of the state, ${ }^{75}$ but the significance of these links for gender equality and feminism remains to be analysed. Theoretical debates that would bring the three political projects together are scarce. ${ }^{76}$

In particular, traditional women's organizations have difficulties in addressing the joint impact of neoliberalism, conservatism and nationalism on gender equality. ${ }^{77}$ Their close relationships to political parties that advance these political projects make voicing a strong critique impossible and lead to co-optation and silences that can be interpreted as support for these policies. However, at the same time, the political context shaped by the triangle of neoliberalism, conservatism and nationalism has also provided fertile ground for new feminist actors that do not shy away from directly opposing the three political projects and are also more interested in resisting the combined effects of neoliberalism, conservatism and nationalism. ${ }^{78}$ Feminist actors who take the intersectional approach seriously are more likely than organizations focusing on women or gender equality to treat nationalism and racism as core feminist concerns and engage with the intersections of the three political projects. ${ }^{79}$

\section{Conclusions}

While there are differences between the Nordic countries, it is possible to discern a Nordic discourse on gender equality. This discourse has been traditionally based on a notion of gender equality that is advanced in public life with the help of welfare policies and positive measures. It has foregrounded gender as a binary relationship between women and men and paid less attention to tackling inequalities in relation to the other axis of difference and power such as race and ethnicity. The position of anti-discrimination law has been weaker in the Nordic countries, and has been strongly influenced by the European Union. The second part of the chapter explored the case of Finland and the ways in which feminism and gender equality policies have been shaped by the forces of neoliberalism, conservatism and nationalism. The challenges may be similar to other Nordic countries as well given the strong role played by radicalright populists and anti-feminist and anti-gender-equality groups across the region. The Nordic model faces challenges from multiple directions: neoliberalism questions the governance and bureaucratic structures of gender equality policies, the very trademark of the Nordic gender equality model; conservatism questions the universality of the model to a new extent; and nationalism constructs gender equality as a differentiating value (between majorities and minorities), not a value that unites. At the same time, however, different 
challenges may foster new forms of feminist activism that support development of Nordic gender equality policies and models.

\section{Notes}

1 Siim 2000, Borchorst et al. 2012.

2 Fundamental Rights Agency 2014, Hearn, Strid, Husu \& Verloo 2016.

3 Elomäki, Kantola, Koskinen Sandberg \& Ylöstalo 2019, Koskinen Sandberg 2018.

4 Erikson \& Josefsson 2018, Kantola 2019.

5 Kantola \& Koivunen 2019.

6 Hudson, Rönnblon \& Teghtsoonian 2017.

7 E.g. Brunila 2009, Holli \& Kantola 2007, Kantola, Nousiainen \& Saari 2012.

8 Kantola \& Squires 2010, 2012.

9 Crenshaw 1991.

10 Keskinen, Tuori, Irni \& Mulinari 2009, Melby, Ravn \& Carlsson Wetterberg 2009, Magnusson, Rönnblom \& Silius 2008.

11 Holli \& Kantola 2007.

12 Rönnblom \& Alnbratt 2016, Elomäki, Kantola, Koskinen Sandberg \& Ylöstalo 2018, Elomäki, Kantola, Koivunen and Ylöstalo 2019, Elomäki \& Ylöstalo 2018, 2020.

13 Melby, Ravn \& Carlsson Wetterberg 2009, 4.

14 Borchorst et al. 2012, Borchorst 1999.

15 Borchorst et al. 2012.

16 Kantola 2006.

17 Nousiainen \& Pentikäinen 2017.

18 Borchorst \& Siim 2008, 208, Towns 2002, Jezierska \& Towns 2018.

19 Koskinen Sandberg 2018, see also Koskinen Sandberg, Törnroos \& Kohvakka 2018.

20 Koskinen Sandberg \& Saari 2019, Saari, Kantola \& Koskinen Sandberg 2019.

21 Kantola 2010.

22 Skjeie \& Teigen 2005.

23 Nousiainen 2008.

24 Nousiainen 2005.

25 Nousiainen \& Pylkkänen 2001, 260.

26 Teigen 2015.

27 Nousiainen 2005.

28 Elomäki \& Ylöstalo 2017.

29 Melby, Ravn \& Carlsson Wetterberg 2009, 5.

30 Borchorst et al. 2012, Rolandsen Agustín \& Sata 2013.

31 See Borchorst et al. 2012.

32 Borchorst \& Siim 2002, 93.

33 Kantola 2006, Lindvert 2002.

34 Borchorst \& Siim 2008, 209-210.

35 de los Reyes, Molina \& Mulinari 2003.

36 Mulinari, Keskinen, Irni \& Tuori 2009, 5.

37 Ibid.

38 Borchorst \& Siim 2008, 215.

39 Borchorst et al. 2012.

40 Mulinari, Keskinen, Irni \& Tuori 2009, 5, Norocel 2016, Keskinen, Norocel \& Jørgensen 2016.

41 Kantola 2010.

42 Kantola \& Nousiainen 2012, Borchorst et al. 2012.

43 The Commission had found the Danish transposition of the equal pay directive to be insufficient and the infringement procedure resulted in Denmark appearing before the European Court of Justice. This was an example of a clash between the Nordic model 
of ensuring equal pay through collective agreements and the EU anti-discrimination model where the Court found that the Nordic model did not sufficiently ensure pay equity. The EU law also expanded the meaning of equal treatment and extended the rights of pregnant workers against dismissal and indirect discrimination in Denmark. Similar changes in equality legislation have taken place in Finland and Sweden after the countries became EU members in the 1990s (Holli \& Kantola 2007, Nousiainen 2005).

44 Brunila 2009.

45 Kantola \& Nousiainen 2012.

46 Eräranta \& Kantola 2016.

47 Elomäki \& Kantola 2018.

48 E.g. Brown 2006, Phipps 2014, Porter 2012.

49 Elomäki \& Kantola 2018.

50 See ibid.

51 Holli 2003.

52 Elomäki \& Kantola 2018.

53 E.g. Julkunen 2010, Heiskala \& Kantola 2010, Kantola \& Kananen 2013.

54 Cf. Walby 2015.

55 Elomäki \& Kantola 2018.

56 Ibid.

57 Ibid.

58 Elomäki \& Ylöstalo 2017, Elomäki, Kantola, Koskinen Sandberg \& Ylöstalo 2019.

59 Elomäki \& Kantola 2018.

60 Jauhola \& Lyytikäinen 2020.

61 See Elomäki \& Kantola 2018, Norocel 2013.

62 Kantola \& Lombardo 2019, Keskinen, Norocel \& Jørgensen 2016, Ylä-Anttila \& Luhtakallio 2017.

63 Pellander 2015.

64 Keskinen 2012, 2013, Elomäki \& Kantola 2018.

65 See Elomäki \& Kantola 2018.

66 E.g. Bakker 2003, Brown 2015, Bargawi, Cozzi \& Himmelweit 2017.

67 Verloo 2016.

68 Yuval-Davis 1997.

69 Keskinen 2012, 2013, Mulinari \& Neergaard 2014, see Elomäki \& Kantola 2018.

70 See Elomäki \& Kantola 2018.

71 Brown 2006.

72 Knight \& Rodgers 2012.

73 Phipps 2014, 12.

74 E.g. Köttig, Bitzan \& Petö 2017.

75 E.g. Keskinen, Norocel \& Jørgensen 2016.

76 Elomäki \& Kantola 2018.

77 Ibid.

78 Elomäki, Kantolaa, Koivunen \& Ylöstalo 2020.

79 Elomäki \& Kantola 2018.

\section{References}

Bakker, Isabella, 2003: "Neo-Liberal Governance and the Privatization of Social Reproduction: Social Provisioning and Shifting Gender Orders" in Isabella Bakker \& Stephen Gill (eds.) Power, Production and Social Reproduction. Basingstoke: Palgrave Macmillan, 66-82.

Bargawi, Hannah, Cozzi, Giuseppe \& Himmelweit, Susan (eds.) 2017: Economics and Austerity in Europe. Gendered Impacts and Sustainable Alternatives. London: Routledge.

Borchorst, Anette, 1999: "Equal Status Institutions" in Christina Bergqvist, Anette Borchorst, Ann-Dorte Christensen, Viveca Ramstedt-Silén, Nina C. Raaum \& Auður 
Styrkasdottir (eds.) Equal Democracies? Gender and Politics in the Nordic Countries. Oslo: Scandinavian University Press, 167-189.

Borchorst, Anette, Freidenvall, Lenita, Kantola, Johanna, Reisel, Liza \& Teigen, Mari, 2012: "Institutionalising Intersectionality in the Nordic Countries? Anti-Discrimination and Equality in Denmark, Finland, Norway and Sweden" in Andrea Krizsan, Hege Skjeie \& Judith Squires (eds.) Institutionalizing Intersectionality? The Changing Nature of European Equality Regimes. Basingstoke: Palgrave Macmillan, 59-88.

Borchorst, Anette \& Siim, Birte, 2002: “The Women-Friendly Welfare State Revisited” in Nora: Nordic Journal of Women's Studies, 10:2, 90-98.

Borchorst, Anette \& Siim, Birte, 2008: "Woman-Friendly Policies and State Feminism: Theorizing Scandinavian Gender Equality" in Feminist Theory, 9:2, 207-224.

Brown, Wendy, 2006: “American Nightmare: Neoliberalism, Neoconservatism, and DeDemocratization" in Political Theory, 34:6, 690-714.

Brown, Wendy, 2015: Undoing the Demos. Neoliberalism's Stealth Revolution. New York: Zone Books.

Brunila, Kristiina, 2009: Parasta ennen. Tasa-arvotyön projektitapaistuminen. Department of Education, Research Report 222. Helsinki: University of Helsinki.

Crenshaw, Kimberlé, 1991: "Mapping the Margins: Intersectionality, Identity Politics, and Violence Against Women of Color" in Stanford Law Review, 43:6, 1241-1299.

de los Reyes, Paulina, Molina, Irene \& Mulinari, Diana, 2003: Maktens (o)lika förklädnader. Kön, klass \& etnicitet $i$ det postkoloniala Sverige. Stockholm: Atlas.

Elomäki, Anna \& Kantola, Johanna, 2018: "Theorizing Feminist Struggles in the Triangle of Neoliberalism, Conservatism, and Nationalism" in Social Politics, 25:3, 337-360.

Elomäki, Anna, Kantola, Johanna, Koivunen, Anu \& Ylöstalo, Hanna, 2019: “Affective Virtuosity: Challenges for Governance Feminism in the Context of the Economic Crisis" in Gender, Work \& Organization. https://doi.org/10.1111/gwao.12313.

Elomäki, Anna, Kantola, Johanna, Koivunen Anu \& Ylöstalo, Hanna, 2020: "Samettikolmiosta uuteen politisoitumiseen: muuttuva feministinen toimijuus" in Johanna Kantola, Paula Koskinen Sandberg \& Hanna Ylöstalo (eds.) Tasa-arvopolitiikan suunnanmuutos. Helsinki: Gaudeamus.

Elomäki, Anna, Kantola, Johanna, Koskinen Sandberg, Paula \& Ylöstalo, Hanna, 2019: "Tasa-arvopoliitikan toteuttaminen Suomessa 2010-luvulla" in Tasa-arvovaltuutetun kertomus eduskunnalle 2018. Tasa-arvojulkaisuja 2018:4. Helsinki: Ombudsman for Equality, 147-177.

Elomäki, Anna \& Ylöstalo, Hanna, 2017: “Tasa-arvopolitiikan U-käännös?” in Politiikasta.fi. https://politiikasta.fi/tasa-arvopolitiikan-u-kaannos/ [Accessed 1 October 2019].

Elomäki, Anna \& Ylöstalo, Hanna (eds.) 2018: Gender Equality in the Government BudgetGender Impact Assessment of the Budget and Gender Budgeting. Publications of the Government's Analysis, Assessment and Research Activities 52/2018. Helsinki: Prime Minister's Office.

Elomäki, Anna \& Ylöstalo, Hanna, 2020: “Talous on tasa-arvokysymys: taloudellistunut tasaarvo ja sukupuolisokea talouspolitiikka" in Johanna Kantola, Paula Koskinen Sandberg \& Hanna Ylöstalo (eds.) Tasa-arvopolitiikan suunnanmuutos. Helsinki: Gaudeamus.

Eräranta, Kirsi \& Kantola, Johanna, 2016: "The Europeanization of Nordic Gender Equality: A Foucauldian Analysis of Reconciling Work and Family" in Gender, Work E Organization, 23:4, 414-430.

Erikson, Josefina \& Josefsson, Cecilia, 2018: "The Legislature as a Gendered Workplace: Exploring Members of Parliament's Experiences of Working in the Swedish Parliament" in International Political Science Review. Online first. https://doi.org/10.1177/01925121 17735952. 


\section{4}

Johanna Kantola

Fundamental Rights Agency, 2014: Violence Against Women: An EU-Wide Survey. Luxembourg: Publications Office of the European Union. https://fra.europa.eu/sites/ default/files/fra_uploads/fra-2014-vaw-survey-main-results-apr14_en.pdf [Accessed 1 October 2019].

Hearn, Jeff, Strid, Sofia, Husu, Liisa \& Verloo, Mieke, 2016: "Interrogating Violence Against Women and State Violence Policy: Gendered Intersectionalities and the Quality of Policy in The Netherlands, Sweden and the UK" in Current Sociology, 64:4, 551-567.

Heiskala, Risto \& Kantola, Anu, 2010: "Vallan uudet ideat: hyvinvointivaltion huomasta valmentajavaltion valvontaan" in Petteri Pietikäinen (ed.) Valta Suomessa. Helsinki: Gaudeamus, 124-148.

Hernes, Helga M., 1987: Welfare State and Woman Power: Essays in State Feminism. Oslo: Norwegian University Press.

Holli, Anne M., 2003: Discourse and Politics of Gender Equality in Late Twentieth Century Finland. Helsinki: University of Helsinki.

Holli, Anne M. \& Kantola, Johanna, 2007: "State Feminism Finnish Style: Strong Policies Clash with Implementation Problems" in Joyce Outshoorn \& Johanna Kantola (eds.) Changing State Feminism. Basingstoke: Palgrave Macmillan, 82-102.

Hudson, Christine, Rönnblon, Malin \& Teghtsoonian, Katherine (eds.) 2017: Gender, Governance and Feminist Post-structuralist Analysis: Missing in Action? London: Routledge.

Jauhola, Marjaana \& Lyytikäinen, Minna, 2020: "Kutistettu feminismi? Suomen ulkosuhteiden tasa-arvopolitiikan muutokset ja pysyvyydet kylmän sodan YK-feminismistä 2010-luvun ulkopolitiikan tolkkutasa-arvoon" in Johanna Kantola, Paula Koskinen Sandberg \& Hanna Ylöstalo (eds.) Tasa-arvopolitiikan suunnanmuutos. Helsinki: Gaudeamus.

Jezierska, Katarzyna \& Towns, Ann, 2018: “Taming Feminism? The Place of Gender Equality in the 'Progressive Sweden' Brand” in Place Branding and Public Diplomacy, 14:1, 55-63. Julkunen, Raija, 2010: Sukupuolen järjestykset ja tasa-arvon paradoksit. Tampere: Vastapaino.

Kantola, Anu \& Kananen, Johannes, 2013: "Seize the Moment: Financial Crisis and the Making of the Finnish Competition State" in New Political Economy, 18:6, 811-826.

Kantola, Johanna, 2006: Feminists Theorize the State. Basingstoke and New York: Palgrave Macmillan.

Kantola, Johanna, 2010: Gender and the European Union. Basingstoke and New York: Palgrave Macmillan.

Kantola, Johanna, 2019: "Women's Organizations of Political Parties: Formal Possibilities, Informal Challenges and Discursive Controversies" in NORA - Nordic Journal of Feminist and Gender Research, 27:1, 4-21.

Kantola, Johanna \& Koivunen, Anu, 2019: Too Much, Too Little? Comparing \#Metoo Campaigns in Finnish and Swedish Politics and media. Paper presented at the European Conference on Politics and Gender, University of Amsterdam, the Netherlands, 4-6 July 2019.

Kantola, Johanna \& Lombardo, Emanuela, 2019: "Populism and Feminist Politics: The Cases of Finland and Spain" in European Journal of Political Research (EJPR), 29, 1-21.

Kantola, Johanna \& Nousiainen, Kevät, 2012: "Euroopan unionin tasa-arvopolitiikka: velvoittavaa lainsäädäntöä ja pehmeää sääntelyä” in Johanna Kantola, Kevät Nousiainen \& Milja Saari (eds.) Tasa-arvo toisin nähtynä: oikeuden ja politiikan näkökulmia tasa-arvoon ja yhdenvertaisuuteen. Helsinki: Gaudeamus, 124-142.

Kantola, Johanna, Nousiainen, Kevät \& Saari, Milja, 2012: "Johdanto: Tasa-arvosta ja sen lukemisesta toisin” in Johanna Kantola, Kevät Nousiainen \& Milja Saari (eds.) Tasa-arvo toisin nähtynä: oikeuden ja politiikan näkökulmia tasa-arvoon ja yhdenvertaisuuteen. Helsinki: Gaudeamus, 7-30. 
Kantola, Johanna \& Squires, Judith, 2010: "The New Politics of Equality" in Colin Hay (ed.) New Directions in Political Science. Basingstoke and New York: Palgrave Macmillan, 88-108.

Kantola, Johanna \& Squires, Judith, 2012: "From State Feminism to Market Feminism” in International Political Science Review, 13:3, 382-400.

Keskinen, Suvi, 2012: "Limits to Speech? The Racialized Politics of Gendered Violence in Denmark and Finland" in Journal of Intercultural Studies, 33:3, 261-274.

Keskinen, Suvi, 2013: “Antifeminism and White Identity Politics. Political Antagonisms in Radical Right-Wing Populist and Anti-Immigration Rhetoric in Finland" in Nordic Journal of Migration Research, 3:4, 225-232.

Keskinen, Suvi, Norocel, Ov Cristian \& Jørgensen, Martin Bak, 2016: "The Politics and Policies of Welfare Chauvinism Under the Economic Crisis" in Critical Social Policy, 36:3, 321-329.

Keskinen, Suvi, Tuori, Salla, Irni, Sari \& Mulinari, Diana (eds.) 2009: Complying with Colonialism Gender, Race and Ethnicity in the Nordic Region. Farnham: Ashgate.

Knight, Melanie \& Rodgers, Kathleen, 2012: "The Government is Operationalizing NeoLiberalism: Women's Organizations, Status of Women, and the Struggle for Progressive Social Change in Canada" in NORA - Nordic Journal of Feminist and Gender Research, 20:4, 266-282.

Koskinen Sandberg, Paula, 2018: "The Corporatist Regime, Welfare State Employment, and Gender Pay Inequity" in NORA - Nordic Journal of Feminist and Gender Research, 26:1, 36-52.

Koskinen Sandberg, Paula \& Saari, Milja, 2019: "Sisters (can't) Unite! Wages as MacroPolitical and the Gendered Power Orders of Corporatism" in Gender, Work \& Organization, 26:5, 633-649.

Koskinen Sandberg, Paula, Törnroos, Maria \& Kohvakka, Roosa, 2018: “The Institutionalised Undervaluation of Women's Work: The Case of Local Government Sector Collective Agreements" in Work, Employment and Society, 32:4, 707-727.

Köttig, Michaela, Bitzan, Renate \& Petö, Andrea (eds.) 2017: Gender and Far Right Politics in Europe. Basingstoke: Palgrave Macmillan.

Lindvert, Jessica, 2002: "A World Apart. Swedish and Australian Gender Equality Policy" in NORA, 10:2, 99-107.

Magnusson, Eva, Rönnblom, Malin \& Silius, Harriet (eds.) 2008: Critical Studies of Gender Equalities. Nordic Dislocations, Dilemmas and Contradictions. Stockholm: Makadam.

Melby, Kari, Ravn, Anna-Birte \& Carlsson Wetterberg, Christina (eds.) 2009: Gender Equality and Welfare Politics in Scandinavia: The Limits of Ambition? Bristol: Policy Press.

Mulinari, Diana, Keskinen, Suvi, Irni, Sari \& Tuori, Salla, 2009: "Introduction: Postcolonialism and the Nordic Models of Welfare and Gender" in Suvi Keskinen, Salla Tuori, Sari Irni \& Diana Mulinari (eds.) Complying with Colonialism: Gender, Race and Ethnicity in the Nordic Region. London: Routledge, 1-18.

Mulinari, Diana \& Neergaard, Anders, 2014: “We are Sweden Democrats Because We Care for Others: Exploring Racisms in the Swedish Extreme Right" in European Journal of Women's Studies, 21:1, 43-56.

Norocel, Ov Cristian, 2013: Our People a Tight-Knit Family Under the Same Protective Roof: A Critical Study of Gendered Conceptual Metaphors at Work in Radical Right Populism. Helsinki: University of Helsinki.

Norocel, Ov Cristian, 2016: "Populist Radical Right Protectors of the Folkhem: Welfare Chauvinism in Sweden" in Critical Social Policy, 36:6, 371-390. 
Nousiainen, Kevät, 2005: “Tasa-arvon monet kasvot. Kansainvälisistä vaikutuksista Suomen tasa-arvo-oikeudessa" in Lakimies, 7-8:2015, 1188-1209.

Nousiainen, Kevät, 2008: "Utility-Based Equality and Disparate Diversities" in Dagmar Schiek \& Victoria Chege (eds.) European Union Anti-Discrimination Law. London: Routledge, 187-214.

Nousiainen, Kevät \& Pentikäinen, Merja, 2017: "Naisiin kohdistuva väkivalta ihmisoikeuskysymyksenä: Suomi alisuorittajana" in Johanna Niemi, Heini Kainulainen \& Päivi Honkatukia (eds.) Sukupuolistunut väkivalta: Oikeudellinen ja sosiaalinen ongelma. Tampere: Vastapaino, 51-67.

Nousiainen, Kevät \& Pylkkänen, Anu, 2001: Sukupuoli ja oikeuden yhdenvertaisuus. Helsinki: University of Helsinki.

Pellander, Saara, 2015: “ “An Acceptable Marriage': Marriage, Migration and Moral Gatekeeping in Finland" in Journal of Family Issues, 36:11, 1472-1489.

Phipps, Allison, 2014: Politics of the Body: Gender in a Neoliberal and Neoconservative Age. Cambridge: Polity Press.

Porter, Ann, 2012: "Neoconservatism, Neoliberalism and Social Policy in Canada. Challenges for Feminism” in Canadian Women's Studies, 29:3, 19-31.

Rolandsen Agustín, Lise \& Sata, Robert, 2013: "Gendered Identity Constructions in Political Discourse: The Cases of Denmark and Hungary" in Monika Mokre \& Birte Siim (eds.) Negotiating Gender and Diversity in an Emergent European Public Sphere. Basingstoke: Palgrave Macmillan, 60-77.

Rönnblom, Malin \& Alnbratt, Kerstin, 2016: Feminism som byråkrati: jämmstäldhetsintegrering som strategi. Stockholm: Leopard Förlag.

Saari, Milja, Kantola, Johanna \& Koskinen Sandberg, Paula, 2019: "Implementing Equal Pay Policy: Clash Between Gender Equality and Corporatism" in Social Politics, 1-25, June 2019.

Siim, Birte, 2000: Gender and Citizenship: Politics and Agency in France, Britain, and Denmark. New York: Cambridge University Press.

Skjeie, Hege \& Teigen, Mari, 2005: "Political Constructions of Gender Equality: Travelling towards . . . a Gender Balanced Society?” in NORA Nordic Journal of Women's Studies, 13:3, 187-197.

Teigen, Mari, 2015: Gender Quotas for Corporate Boards in Norway. EUI Department of Law Research Paper No. 2015/22. SSRN. https://ssrn.com/abstract=2617172 or http:// dx.doi.org/10.2139/ssrn.2617172.

Towns, Anne, 2002: "Paradoxes of Gender (In)Equality: Something is Rotten in the Gender Equal State of Sweden" in Cooperation and Conflict, 37:2, 157-179.

Verloo, Mieke, 2016: Should We (Re)Consider Conservatism to be an Anti-Feminist Force? Unpublished manuscript.

Walby, Sylvia, 2015: Crisis. Cambridge: Polity Press.

Ylä-Anttila, Tuukka \& Luhtakallio, Eeva, 2017: "Contesting Gender Equality Politics in Finland: The Finns Party Effect” in Michaela Köttig, Renate Bitzan \& Andrea Petö (eds.) Gender and Far Right Politics in Europe. Basingstoke: Palgrave Macmillan, 29-48.

Yuval-Davis, Nira, 1997: Gender and Nation. London: Sage Publications. 